\title{
Emission Characteristics for Waste Cooking Oil Biodiesel Blend in a Marine Diesel Propulsion Engine
}

\author{
Gang Wu*, Guohe Jiang, Zhiyuan Yang, Zhijian Huang \\ Merchant Marine College, Shanghai Maritime University, Shanghai, China
}

Received: 12 April 2018

Accepted: 29 June 2018

\begin{abstract}
Diesel engines are widely used for propulsion on large ships, which has the undesired characteristic of generating large amounts of harmful emissions. To reduce these emissions, some alternative fuel was developed and used in a marine diesel engine. In this study, an experiment was carried out on a 6-cylinder turbocharged direct-injection marine diesel propulsion engine. A small proportion blend of biodiesel-diesel was used, aimed at exploring the emission characteristics and emission reduction mechanism for diesel propulsion engines. The results show that the high oxygen content of biodiesel blend is crucial for inhibiting the formation of particulate matter (PM) and reducing the formation of total unburned hydrocarbon (THC) and carbon monoxide (CO), which reduces the emission of harmful gases. At the same time, the number of particles (PN) has also decreased. However, the rapid burn rate of biodiesel was found to reduce brake thermal efficiency (BTE), resulting in an increase of fuel consumption and exhaust gas temperature (EGT), which can promote the formation of nitrogen oxides $\left(\mathrm{NO}_{\mathrm{x}}\right)$. More carbon dioxide $\left(\mathrm{CO}_{2}\right)$ is released due to the increased fuel consumption. The emission characteristics of the biodiesel blend and diesel fuel are discussed in this work.
\end{abstract}

Keywords: waste cooking oil biodiesel; marine propulsion diesel engine; emissions characteristics

\section{Introduction}

Issues of energy scarcity, concerns over fluctuations in fuel prices and environmental pollution associated with global warming are the most disturbing problems encountered as far as sea transport is concerned. Ships provide means for logistics, passenger transport, and national defense. Moreover, more than $90 \%$ of international trade is now conducted via ocean-going

*e-mail: wugang@shmtu.edu.cn vessels [1]. Large ocean-going vessels have three typical characteristics: high fuel consumption, long operation periods and high emission of harmful substances. Compared to land vehicles, ocean-going vessels have higher environmental pollution potential [2-4]. The main emissions released from the combustion of marine engine consists of $\mathrm{NO}_{\mathrm{x}}$, sulphur oxides ( $\left.\mathrm{SOx}\right), \mathrm{CO}, \mathrm{CO}_{2}$, THC and PM. To decrease these harmful emissions, the International Maritime Organization (IMO) has established rules and regulations to strengthen the laws regulating gaseous emissions. All of the above have stimulated interest in the development of alternative 
fuels to replace conventional fossil fuels. An alternative fuel should be technically feasible, economically competitive, environmentally acceptable and readily available [5].

Biodiesel is the fastest growing alternative fuel for diesel engines. This is can be attributed to the natural advantages of biodiesel, such as high flash point, biodegradability, improved cetane number and reduced exhaust emissions $[6,7]$. In addition, biodiesel can blend with conventional diesel in any ratio. The blends are referred to as $\mathrm{BXX}$, where $\mathrm{XX}$ indicates the volume percentage of biodiesel in the mixtures [8]. Another advantage of biodiesel is that it can be used in engines in a similar manner as a conventional fossil fuel without any modification of engine geometry due to its similar physical-chemical properties to diesel [9].

However, as biodiesel is derived from animal fats or vegetables [10], it is controversial to use biodiesel because of its competition with food. Waste cooking oil is a potential alternative feedstock. Using waste cooking oil is a feasible strategy for cutting the cost of raw materials for the production of biodiesel without competition with food [11]. Besides, it will solve the problem of food disposal effectively. As such, there is a worldwide increased interest in applying biodiesel converted from waste cooking oil as a fuel in diesel engines [12-14].

Biodiesel is a mono-alkyl ester with the long chain of fatty acids produced from animal fats or vegetable oils [15]. It is considered a renewable and clean alternative fuel for diesel engines, among other sources [16]. The typical method for producing biodiesel is to generate biodiesel by an esterification reaction [17-19]. The reaction process is carried out using short-chain alcohol such as methanol (or acid or base) as a catalyst [20-22].

Accordingly, considerable research has been conducted in different types of engines with biodiesel prepared from different oils. The effects on the performance parameters of the engine with emission and combustion characteristics of the biodiesel have been studied in these research works. Huzayyin et al. [23] observed an increment in CO emissions when using jojoba oil on a four-stroke diesel engine. The results indicated an increase in fuel consumption and brake thermal efficiency when using biodiesel blended with convectional diesel. The blended fuels could lead to higher $\mathrm{CO}$ and $\mathrm{HC}$ emissions than biodiesel. Pugazhvadivu et al. [24] observed the same trend when using waste frying oil as fuel in a single cylinder diesel engine. They argued that the increment in $\mathrm{CO}$ emissions could be attributed to the relatively inadequate combustion. However, a reduction in NOx emission was observed compared to diesel. The decrease was found to be less with preheated oil. Uyumaz [25] also experimented on a single cylinder, four-stroke, DI diesel engine with mustard oil biodiesel. The results show that low blends of biodiesel are optimum to emission. $\mathrm{NO}_{\mathrm{x}}$ increased while $\mathrm{CO}$ and smoke emissions decreased with biodiesel fuel blends. El-Adawy et al. [26] observed an opposite trend in $\mathrm{NO}_{\mathrm{x}}$ and $\mathrm{CO}$ emissions. They found that the $\mathrm{CO}$ and $\mathrm{HC}$ emissions decreased by 31 and $40 \%$, respectively, whereas $\mathrm{CO}_{2}$ and $\mathrm{NO}_{x}$ increased by 17 and $40 \%$, respectively. It was also found that the ignition delay period decreased and the total combustion duration increased with an increasing percentage of biodiesel in the fuel blend.

In summary, different biodiesels are used in various countries, which are related to their national conditions. However, the diversity of biodiesel, especially in biodiesel sources, production process and the type of engine, has led to complicated emission characteristics and combustion performances for different diesel engines. In addition, the above research results are mostly based on laboratory experiments on land diesel engines. There are very few investigations reported especially in the applications of biodiesel in marine engines. It is therefore in the great interest of the authors to provide an experiment on emissions for waste cooking oil biodiesel blend in a marine diesel propulsion engine.

The aim of this study was to produce biodiesel from waste cooking oil. It was followed by characterizing the biodiesel properties and comparatively assessing the effects of diesel and biodiesel blend on diesel engine performance and emissions characteristics under various concurrently varying loads and speeds. The studied engine is used on small ferries in China, whose gaseous pollution is significant and virtually of less concern. To determine the running condition effects on engine performance and emissions, measurements were taken at E3 condition, namely 25\%, 50\%, 75\% and $100 \%$ propulsion loads. The average amounts under each load were then assessed. This approach was used to determine the effects of load on engine performance and emissions.

\section{Material and Methods}

\section{Experimental Setup}

A six-cylinder four-stroke diesel engine was used for the experiments. The engine's technical specifications are given in Table 1. The engine is usually used for marine propulsion. The emission test was carried out in four diesel engine operating conditions according to the propulsion characteristics, namely $25 \%, 50 \%, 75 \%$ and $100 \%$ loads.

The engine rotational speed is controlled and stabilized by a governor. The cylinder firing order is 1-5-3-6-2-4 for the six-cylinder engine. The value timing angles are IVO $20^{\circ}$ before BDC, EVC $60^{\circ}$ after TDC, IVC $48^{\circ}$ after BDC and EVO $48^{\circ}$ before BDC. A hydraulic dynamometer was employed to apply the load to the engine. Rotation speed sensor was installed on the flywheel at the end of the motor. A computer was used to display the operating parameters of the diesel engine (such as speed, power, torque, exhaust 
Table 1. Engine technical specifications.

\begin{tabular}{|c|c|}
\hline Parameter & Specification \\
\hline Engine Type & 4-stroke engine \\
\hline Application & Marine \\
\hline Aspiration System & Turbocharged with intercooler \\
\hline No. of Cylinders & 6 \\
\hline Compression Ratio & $17: 1$ \\
\hline Rated Speed (rpm) & 1500 \\
\hline Rated Power (kW) & $234 @ 1500 \mathrm{rpm}$ \\
\hline Rated Torque (Nm) & $1000 @ 1500$ rpm \\
\hline Bore (mm) & 135 \\
\hline Stroke $(\mathrm{mm})$ & 150 \\
\hline Displacement (mm) & 1288 \\
\hline Cooling & Forced water circulation \\
\hline $\begin{array}{l}\text { Nozzle Opening pressure } \\
\text { (bar) }\end{array}$ & 240 \\
\hline $\begin{array}{l}\text { Injector (no. of. holes } \\
\times \text { diameter) }\end{array}$ & $5 \times 0.32$ \\
\hline Fuel Delivery System & Rotary distributor type pump \\
\hline $\begin{array}{c}\text { Static Injection Timing } \\
\left({ }^{\circ} \mathrm{CA} \text { BTDC }\right)\end{array}$ & 16 \\
\hline
\end{tabular}

a)

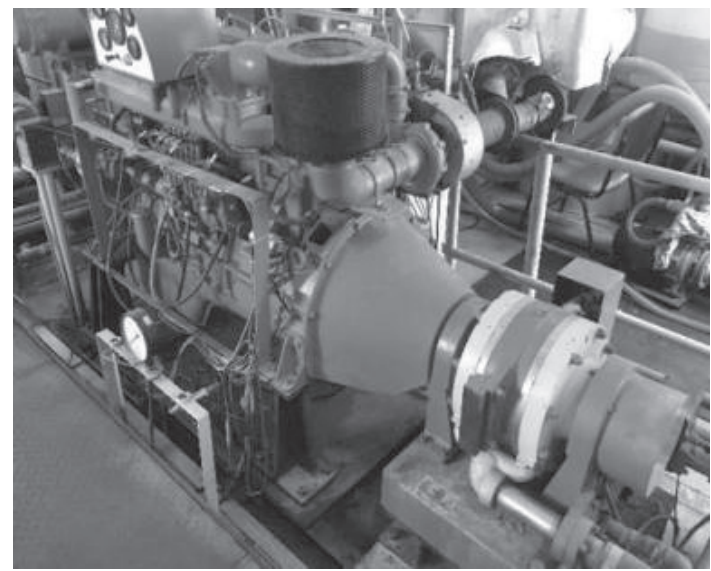

b)

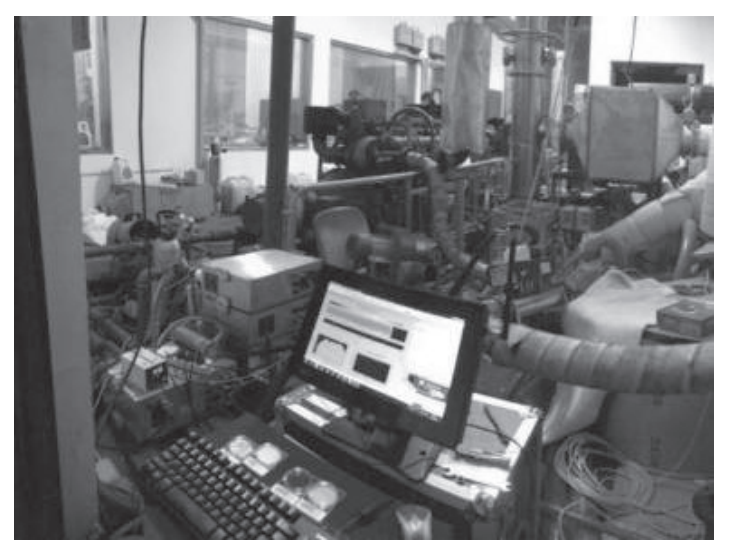

Fig. 1. a) Experimental diesel engine bench; b) Data acquisition system. temperature) via sensors connected to the engine. Fig. 1 shows the experimental diesel engine test bench and data acquisition system.

Fig. 2 is a schematic diagram of the experimental setup and the measurement instrumentation used to test the engine performance and emission characteristics of the fuel blend. It consists of a fuel-flow test system and an emissions test system.

The ratios of the biodiesel blends were adjusted well before the start of the experiment. The diesel and biodiesel fuels were stored in two different fuel tanks. A three-way valve was applied to change the flow of the fuels. After switching the fuel pipelines, the test was not carried out immediately until after 30 minutes of engine running to thoroughly clean the residual oils in the fuel pipe system. A fuel flow meter was used to measure fuel consumption.

The emission test system consists of a module for the gaseous product emissions and a module for the PM emissions. A SEMTECH ECOSTAR gas module was used to detect gaseous pollutant emissions, including $\mathrm{CO}, \mathrm{CO}_{2}, \mathrm{THC}$, nitrogen dioxide (NO) and nitric oxide $\left(\mathrm{NO}_{2}\right)$ concentrations. An $\mathrm{O}_{2}$ concentration detector is also available in this module. SEMTECH MPS coordinate dilution ratio system together with the TSI EEPS-3090 particle analyzer were applied to detect PM and $\mathrm{PN}$ emissions.

\section{Fuel Properties}

Operating characteristics of the engine such as combustion and emission depend on the physicalchemical properties of the fuel used. The composition of fuel, density, viscosity, cetane number, calorific value, flash and pour points are some significant properties that should be considered. According to M.J. Ramos's research [27], the low cetane number of diesel indicates a relatively small content of unsaturated fatty acids. In contrast, the high cetane number of biodiesel means a longer fatty acid carbon chain than that of diesel. Some scholars $[15,16]$ have reported that a higher cetane number of biodiesel implies a shorter ignition delay. The shortened ignition delay would in turn enhance the ignition quality and increase the combustion duration time. Another critical parameter is viscosity, since it may decrease the fuel fluidity in the engine fuel system, especially at low loads. In addition, a higher viscosity means poor combustion atomization, which may result in incomplete combustion. At the same time, carbon deposits may be formed at the injectors [15-17]. The fuel flash point assesses flammability. The presence of double-bonds carbon, as well as the number of carbon atoms, affects the flash point [16]. Therefore, it is necessary to determine the physical-chemical properties of the fuel through further analysis and research before using the biodiesel in the engine.

In this study, two fuels, namely biodiesel blend (B10) produced from waste cooking oil and ultra-low sulfur diesel (D100), were prepared and used. The biodiesel 


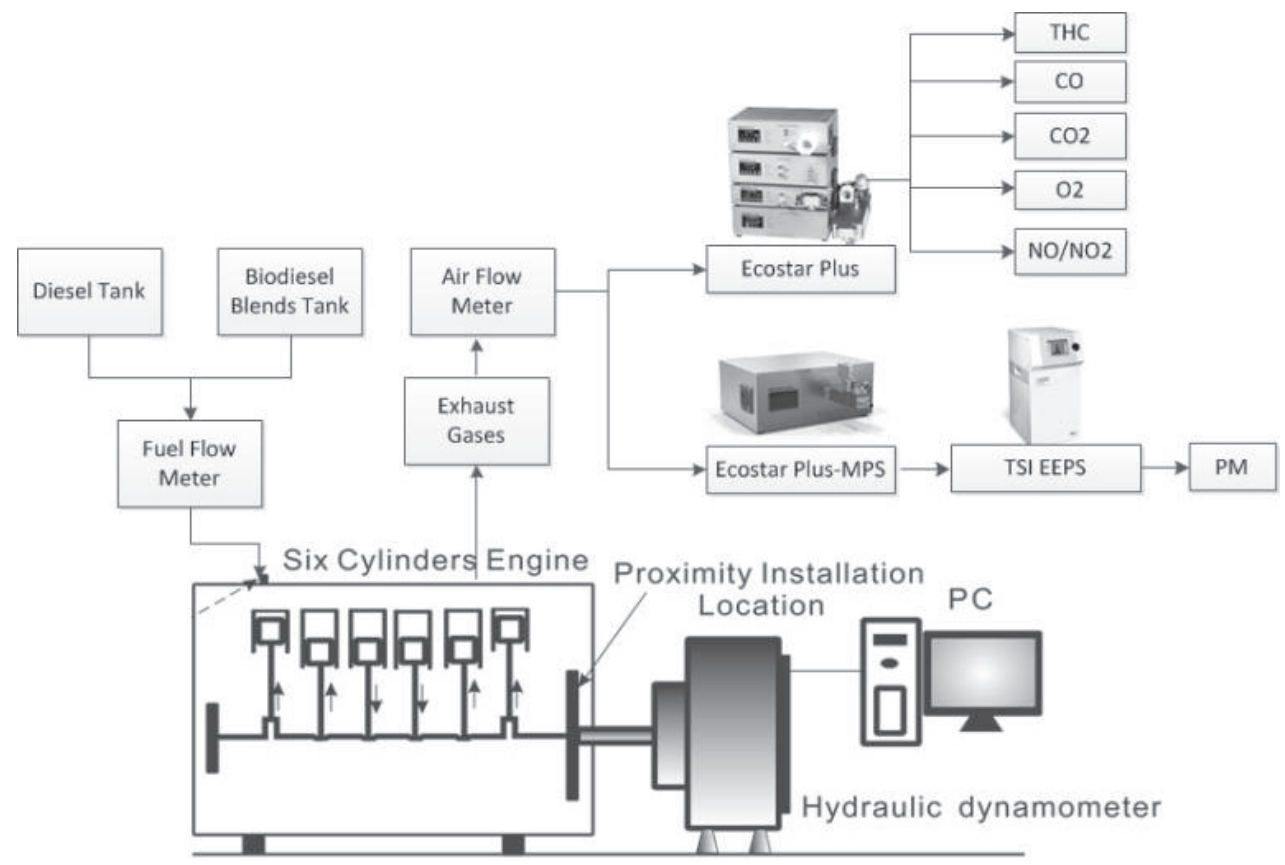

Fig. 2. Experimental set up and measurement instrumentation.

blend and diesel fuel specifications are shown in Table 2. The measurements were based on ASTM standards. The optimum range for the biodiesel blend produced in ASTM is also provided.

Table 2 shows that the two fuel properties are similar in many aspects. For example, the amount of phosphorous and sulfur present in the fuels is small in both fuels, hence the emission of acid gases, such as SOx for these fuels is almost negligible. In addition, both fuels have good lubrication properties due to the low sulfur content. This is very important in reducing wear in cylinder liner surface or the injector nozzle

Table 2, Physical-chemical properties of waste cooking biodiesel and ultra-low sulfur diesel

\begin{tabular}{|c|c|c|c|c|c|}
\hline Parameter & Unit & Test method & D100 & B10 & ASTM limit \\
\hline Acid number & Mg KOH/100ml & ASTM D664 & 2.98 & 5.64 & Max 0.8 (ASTM D664) \\
\hline Oxidation stability & Min & ASTM D525 & 0.7 & 1.1 & Min 3 h (EN 14112) \\
\hline Copper corrosion @373 K for three $\mathrm{h}$ & - & ASTM D130 & $1 \mathrm{a}$ & $1 \mathrm{a}$ & Max 3a \\
\hline Distillation temperature (90\%) & $\mathrm{K}$ & ASTM D6352 & 595.2 & 601.2 & Max 360 (ASTM D1160) \\
\hline Cloud point & $\mathrm{K}$ & ASTM D2500 & 271 & 271 & No Limit \\
\hline Pour point & $\mathrm{K}$ & ASTM D97 & 265 & 265 & No Limit \\
\hline Heat of combustion & $\mathrm{MJ} / \mathrm{kg}$ & ASTM D240 & 43.12 & 42.59 & No Limit \\
\hline Density @303 K & $\mathrm{mg} / \mathrm{m}{ }^{3}$ & ASTM D7042 & 0.8207 & 0.8269 & No Limit \\
\hline Kinematic viscosity @ 313 K & $\mathrm{mm} / \mathrm{s}$ & ASTM D7042 & 2.516 & 2.628 & $1.9-6$ @313 K (A ASTM D445) \\
\hline Sulfated ash & Mass\% & ASTM D874 & 0.02 & 0.02 & Max0.02 (ASTM D874) \\
\hline Flashpoint & $\mathrm{K}$ & ASTM D92 & 338 & 341 & Min 93 (ASTM D93) \\
\hline Carbon residue & Mass\% & ASTM D524 & 0.0002 & 0.0002 & Max 0.05 (ASTM D4530) \\
\hline Water content & Mass\% & ASTM D7042 & 0.05 & 0.05 & Max 0.05\%Vol (ASTM D2709) \\
\hline Cetane Number & - & ASTM D613 & 52.3 & 52.4 & Min 47 (ASTM D613) \\
\hline C content & Mass\% & ASTM D5291 & 85.44 & 84.89 & No Limit \\
\hline H content & Mass\% & ASTM D5291 & 13.83 & 13.69 & No Limit \\
\hline O content & ASTM D5291 & 0.73 & 1.42 & No Limit \\
\hline
\end{tabular}


holes. Moreover, fluidity properties at low temperatures are indicated by cloud point and pour point. As the two fuels have the same cloud point and pour point, it is unlikely that there will be a challenge in engine operation while using the biodiesel blend in cold weather. However, there are some differences in the properties of the two fuels. The main disadvantage of B10 biodiesel blend is the calorific value, which is slightly lower than D100 diesel. The calorific value is an indicator of fuel energy content. Since biodiesel contains more oxygen by weight, its higher calorific value and lower calorific value are relatively lower than that of diesel [28]. The advantage of B10 biodiesel blend is its higher flash point, which poses little challenges as far as its storage and transportation are concerned.

\section{Results and Discussion}

\section{Fuel Consumption and Brake-Specific Fuel Consumption (BSFC)}

The BSFC is defined as the ratio of fuel mass flow to the engine brake power. It is an essential indicator of fuel economy to the engine. It is calculated by using the following equation:

$$
\left[\mathrm{BSFC}=\frac{\mathrm{m}_{\text {fuel }}}{\mathrm{P}} \times 10^{3}(\mathrm{~g} / \mathrm{kw} \cdot \mathrm{hr})\right]
$$

...where $\mathrm{m}_{\text {fuel }}$ is the fuel consumption in $\mathrm{kg} / \mathrm{h}$ and $\mathrm{P}$ is the engine power in $\mathrm{kW}$; the experimental results for BSFC are shown in Fig. 3b).

The measured fuel consumption and calculated BSFC with the biodiesel blend compared to the diesel fuel is shown in Fig. 3, which shows fuel consumption and brake-specific fuel consumption for the two samples of fuel against different loads. As can be seen, under the same engine operation conditions biodiesel blend has a higher fuel consumption and brake-specific fuel consumption compared to diesel. Relative to the diesel fuel, BSFC under $25 \%, 50 \%, 75 \%$ and $100 \%$ load for B10 have increased by $7.32 \%, 4.99 \%, 3.52 \%$ and $1.62 \%$, respectively, as shown in Fig. 3a). The percentage increase in brake specific fuel consumption for B10 at different loads were found to be similar to that for diesel fuel combustion as in Fig. 3b).

The oxygen contents of D100 and B10 are 0.73 and 1.42 , respectively. Naturally, biodiesels have high oxygen content, and the oxygen content does not contribute to heat generation during combustion. Hence, the low heating value is a crucial factor affecting fuel consumption increase. Some research has also argued that the most important factor that results in the increased BSFC for biodiesel is the decreased biodiesel fuel heating value $[29,30]$. Besides the heating value, viscosity and density play significant roles in increasing BSFC. The higher viscosity of B10 affects its fluidity, which may cause pressure fluctuations in the fuel feed pipeline at low temperatures. This could lead to poor atomization during combustion and may cause incomplete combustion or carbon deposits at the injectors at low-load engine operations [9]. Hence, the increased percentage of BFSC is more significant at low loads. Also, the densities of D100 and B10 are 0.8207 and 0.8269 , respectively. In each injection cycle, the action of the isometric displacement oil discharge valve means that a fixed volume of fuel is injected into the combustion chamber, resulting in more mass fuel consumption for B10.

\section{EGT and BTE}

Heat release rate of fuel during the combustion period [31] is the key to engine power performance. As the combustion occurs in the cylinder, it is not easy to be observed. The EGT, however, is a relatively easy parameter to measure and deduce important information for combustion condition monitoring. It is related to the in-cylinder combustion and cooling. Higher engine power or higher fuel consumption rate can cause higher EGT [32].

As can be seen, under the same engine running conditions the biodiesel has a higher EGT as compared
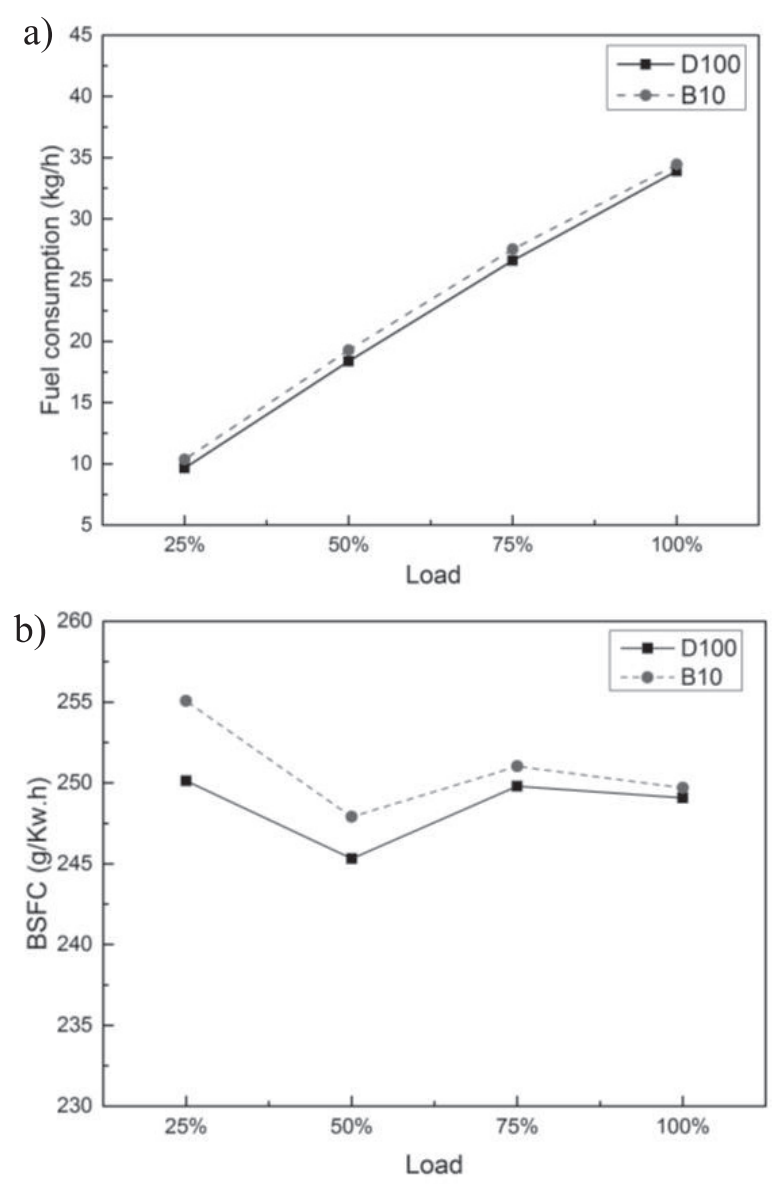

Fig. 3. a) Fuel consumption of biodiesel and diesel against load; b) Brake-specific fuel consumption of biodiesel and diesel against load. 
to diesel. This is a clear indication that the calorific value of B10 is relatively lower than diesel. Compared to the diesel fuel, EGT values under $25 \%, 50 \%, 75 \%$ and $100 \%$ load for B10 increased by $0.35 \%, 1.13 \%, 0.72 \%$ and $1.92 \%$, respectively, as shown in Fig. 4a). The reason for this kind of variation is the improved combustion due to the oxygenated nature of the biodiesel fuel, which led to complete combustion.

BTE is the ratio of engine power to the thermal energy released by fuel combustion under unit time. It is calculated by the following equation:

$$
\left[\mathrm{BTE}=\mathrm{P} \cdot\left(\frac{\mathrm{m}_{\text {fuel }} \cdot Q_{L H V}}{3600}\right)^{-1} \times 100(\%)\right]
$$

...where $\mathrm{m}_{\text {fue }} \mathrm{l}$ is the fuel consumption in $\mathrm{kg} / \mathrm{h}$; $\mathrm{P}$ is the engine power in $\mathrm{kW}$; and QLHV is the lower heating value of the tested fuel in $\mathrm{kJ} / \mathrm{kg}$. The result of BTE is shown in Fig. 4b).

It can be observed that the biodiesel has a lower BTE in comparison with diesel. The BTE increases with increasing engine load from $25 \%$ to $50 \%$ load and then slightly decreases after reaching the peak at $50 \%$ load. Relative to the diesel fuel, BTE values under $25 \%, 50 \%, 75 \%$ and $100 \%$ load for B10 decreased by $0.71 \%, 0.19 \%, 0.74 \%$ and $0.98 \%$, respectively. In this case, there is reduced air-fuel ratio in the cylinder
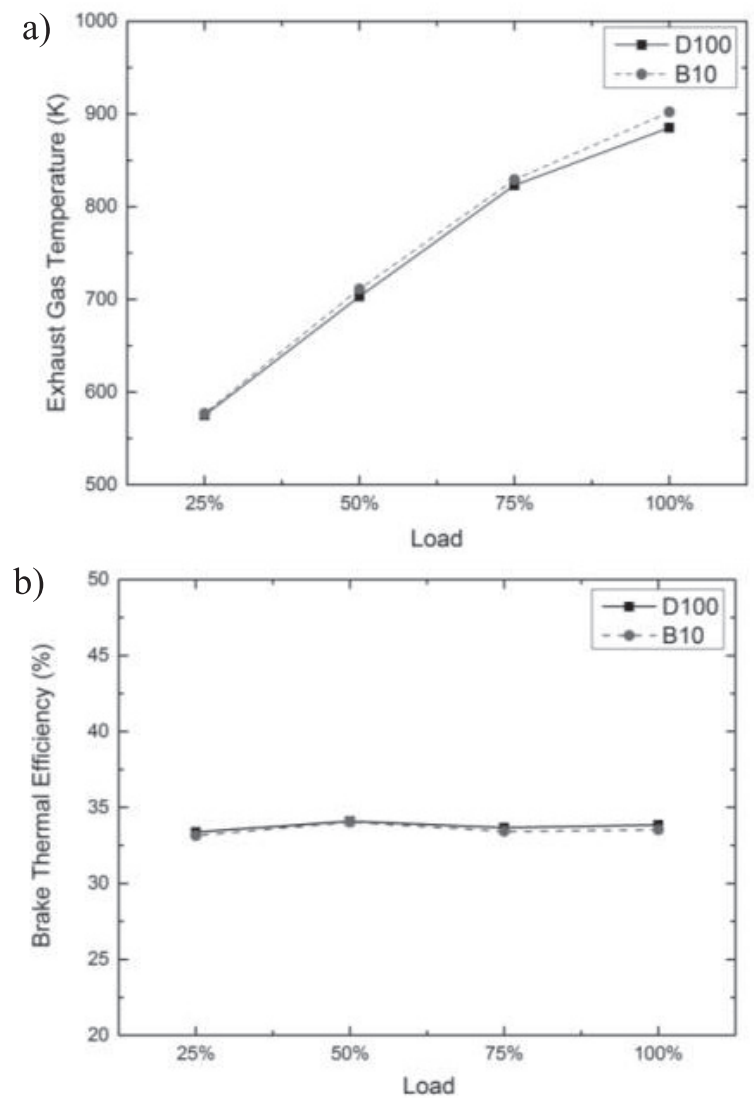

Fig. 4. a) EGT of biodiesel and diesel against load; b) BTE of biodiesel and diesel against load. because of limited turbocharger capability and more injected fuel in the combustion chamber under high load.

Compared to the diesel fuel, the oxygenated nature of biodiesel helps to improve the combustible mixture and promote complete combustion. However, in the performance of BTE, incomplete combustion due to poor atomization and low calorific value of B10 play a more significant role in the decrease of BTE. Still, the decreased BTE of B10 biodiesel is acceptable.

\section{$\mathrm{CO}$ and $\mathrm{CO}_{2}$ Emissions}

Fig. 5 shows $\mathrm{CO}$ content and $\mathrm{CO}_{2}$ content for the biodiesel-diesel fuel blends compared to the diesel fuel at different engine loads. Compared to the diesel fuel, measured $\mathrm{CO}$ emissions value, Fig. 5a), under 25\%, 50\%, $75 \%$ and $100 \%$ load condition for B10 fuel decreased by $4.27 \%, 4.00 \%, 10.40 \%$ and $25.17 \%$, respectively. The main reason for the decrease in $\mathrm{CO}$ emissions when using biodiesel blend is the oxygen elements contained in biodiesel, which is equivalent to an increase in the air-fuel ratio. The increased possibility of $\mathrm{CO}$ being converted into $\mathrm{CO}_{2}$ manifested as a decrease in $\mathrm{CO}$ emissions. In addition to the oxygen in the fuel molecular structure, there are other factors affecting $\mathrm{CO}$ generation, such as cetane number and viscosity of the fuel. The viscosities of D100 and B10 are 2.516 and 2.628, respectively. Given the higher viscosity of B10 fuel, poor combustion was realized due to a locally created zone of inadequate combustible mixture. This provided a suitable condition for CO formation [14]. Viscosity effect on the $\mathrm{CO}$ generation could have an opposite trend. However, the results show that the role of oxygen for B10 is greater than that of viscosity on $\mathrm{CO}$ generation. The cetane numbers of D100 and B10 are 52.3 and 52.4, respectively. The effect of cetane value in promoting $\mathrm{CO}$ generation is limited for the B10 fuel.

In general, $\mathrm{CO}$ in engine exhaust gas increases with the increase in engine load for both fuels due to an increase in the fuel injected into the engine. Such results have also been expressed by other researchers, and the reason for this trend has been attributed to be the high oxygen content in biodiesel $[33,34]$. The increment was associated with the higher amount of fuel delivered into the cylinder. However, an exception is at the $25 \%$ load, under which $\mathrm{CO}$ emission reaches a maximum compared to other engine conditions for both fuels. The reason for this phenomenon is the high viscosity at low temperatures. Relatively poor combustion and the formation of a locally created zone of inadequate combustible mixture promote $\mathrm{CO}$ formation. With increased load, increased combustion efficiency is realized, and the fuel in the combustion chamber tends to burn completely. Similar trends can also be found for $\mathrm{CO}_{2}$ emission with increasing load.

The measured $\mathrm{CO}_{2}$ emission for $\mathrm{B} 10$ biodiesel increased slightly compared to diesel (Fig. 5b). The reason for this phenomenon is a higher carbon-to- 
hydrogen ratio and the existence of oxygen in the molecular structure $[15,35,36]$.

Under fixed fuel volume, D100 and B10 have $99.27 \%$ and $98.58 \%$ non-oxygen compounds by weight respectively, i.e., carbon and hydrogen. At the same time, carbon to hydrogen ratios of D100 and B10 fuels are 6.179 and 6.201, respectively. Therefore, under fixed volume, a higher number of carbon atoms enter into the cylinder when using diesel than biodiesel.

Similar to $\mathrm{CO}$ emissions, with the increase in engine load, $\mathrm{CO}_{2}$ content in the exhaust gas increased, except for the $25 \%$ load. This can be attributed to a higher number of carbon atoms entering into the combustion chamber. A high carbon-to-hydrogen ratio contributes to increased $\mathrm{CO}_{2}$ emissions. For instance, compared to diesel, B10 under the load of $25 \%, 50 \%$, and $100 \%$ showed an increase in $\mathrm{CO}_{2}$ in exhaust gases of $1.04 \%$, $0.40 \%, 0.88 \%$, and $1.02 \%$ respectively.

An interesting phenomenon observed was that $\mathrm{CO}_{2}$ emission value, as well as percentage differences, reached a minimum under $50 \%$ load for both fuels, although there were increased carbon atoms above $25 \%$ load. This can be attributed to the fuel viscosities. As the combustion temperature rises rapidly, the decreased fuel viscosities may result in an earlier start of injection (SOI) and a prolonged ignition delay, which is conducive for the premixed combustion. It is equivalent
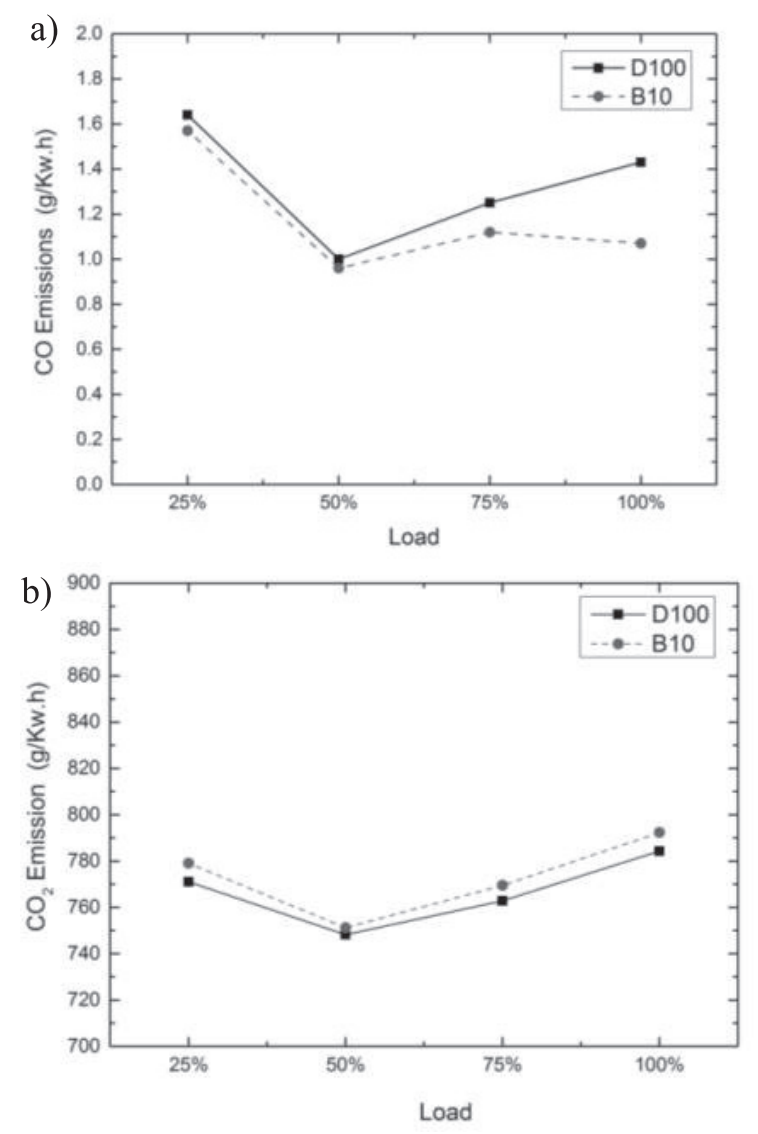

Fig. 5. a) $\mathrm{CO}$ emissions of biodiesel and against load; b) $\mathrm{CO}_{2}$ emissions of biodiesel and diesel against load. to improving the mixing quality of air to fuel, which eventually improves the BTE. This is conducive for the reduction of $\mathrm{CO}_{2}$ emissions in diesel engines.

\section{THC and $\mathrm{NO}_{\mathrm{x}}$ Emissions}

Fig. 6 shows the measured $\mathrm{THC}$ and $\mathrm{NO}_{\mathrm{x}}$ contents for the biodiesel blend compared to the diesel fuel at different speeds against the engine load. With increased load, the measured THC value decreased for both fuels as shown in Fig.6a). Relative to the diesel fuel, measured THC emission value under $25 \%, 50 \%, 75 \%$ and $100 \%$ load conditions for B10 fuel decreased by $10.31 \%$, $11.13 \%, 10.00 \%$ and $41.56 \%$, respectively.

Local quenching effect caused by low temperature at low load promoted the generation of THC. The low airfuel ratio at high load due to the operating limits of the turbocharger encouraged the production of THC as well. However, one reason for the reduced THC is the extra oxygen element contained in B10 biodiesel, which has a deterrent effect on the generation of THC.

Another reason is the high cetane number of B10 biodiesel since it has less unsaturated fatty acids. The high cetane number of $\mathrm{B} 10$ is conducive for complete combustion and helps to inhibit the formation of THC. The low aromatic content of B10 helps to suppress the formation of THC as well.

Nitrogen $\left(\mathrm{N}_{2}\right)$ in the intake air is oxidized to $\mathrm{NO}_{\mathrm{x}}$ in the combustion chamber and discharged in the exhaust stroke. $\mathrm{NO}_{\mathrm{x}}$ includes a variety of compounds. The main compounds of $\mathrm{NO}_{x}$ are $\mathrm{NO}$ and $\mathrm{NO}_{2}$. In comparison with the diesel fuel, measured $\mathrm{NO}_{x}$ emission value (Fig. 6b) under 25\%, 50\%, 75\% and $100 \%$ load condition for $\mathrm{B} 10$ fuel increased by $0.72 \%, 3.26 \%$, $0.80 \%$ and $4.43 \%$, respectively.

$\mathrm{NO}_{x}$ emission is consistent with EGT against the load. This indicates the significant effect of temperature on NOx generation. The variation of $\mathrm{NO}$ and $\mathrm{NO}_{2}$ will be explored in the next subsection.

\section{$\mathrm{NO}$ and $\mathrm{NO}_{2}$ Emissions}

The amount of combustion temperature increase and residence time of such temperature increase inside the high-temperature combustion chamber zone will result in broken nitrogen molecules and the generation of NOx. Since biodiesels are oxygenated fuel compounds, combustion is improved and results in increased maximum combustion temperature inside the combustion chamber. This, in turn, increases in $\mathrm{NO}_{\mathrm{x}}$ existing in the exhaust pipe. Therefore, by adding biodiesel into diesel fuel, the actual NO increases and this trend can be seen in Fig. 7a), which shows nitrogen dioxide (NO) emissions for the biodiesel-diesel fuel blends compared to the diesel fuel at different engine loads. It shows that for B10 under 25\%, 50\%, 75\% and $100 \%$ loads, the measured NO values compared to diesel increased by $1.93 \%, 3.38 \%, 0.82 \%$ and $4.27 \%$, respectively (Fig. 7a). 

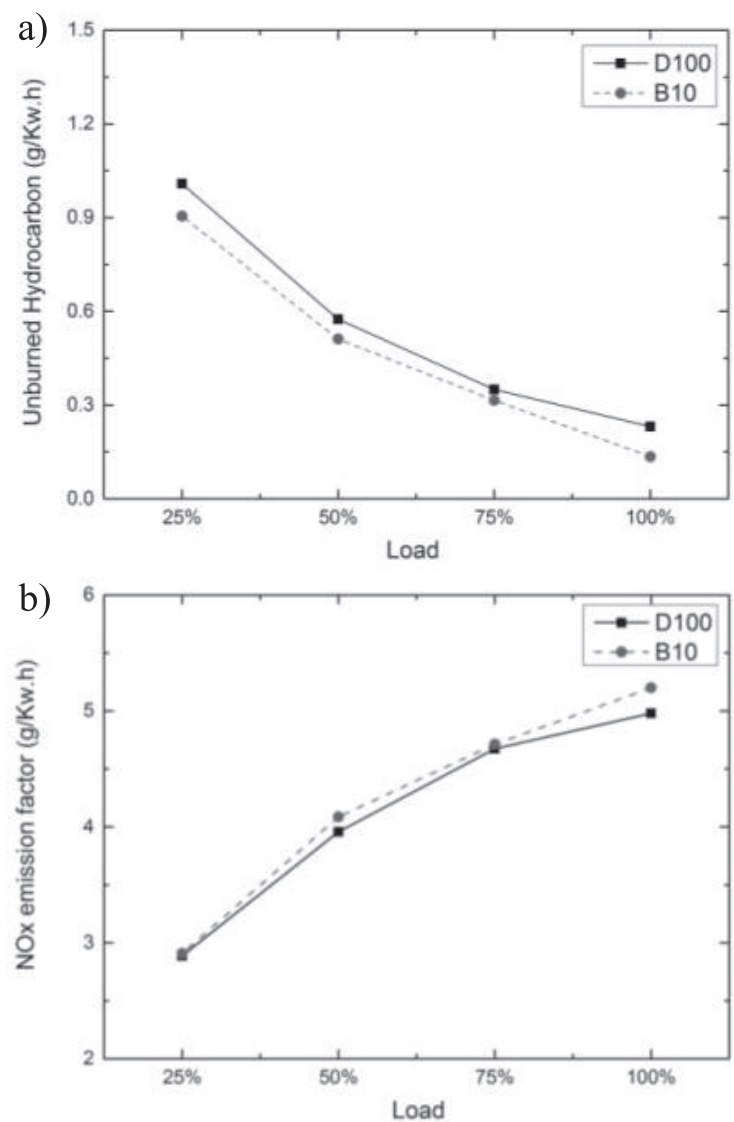

Fig. 6. a) Unburned hydrocarbon emissions of biodiesel and diesel against load; b) $\mathrm{NO}_{\mathrm{x}}$ emissions of biodiesel and diesel against load.

$\mathrm{NO}_{2}$ is mainly produced by the oxidation of $\mathrm{NO}$ under the action of oxygen. Fig. 7b) shows $\mathrm{NO}_{2}$ content for the biodiesel blend compared to the diesel fuel at different engine loads. The measured $\mathrm{NO}_{2}$ emissions value decreased with increasing load for both fuels as depicted in Fig. 7b). As the load increases, the amount of fuel injected into the cylinder increases as well. There is no proportional increase in the amount of air in the combustion chamber due to the fixed cylinder volume and turbocharger capacity, which means that the air-fuel ratio decreased. The oxygen concentration in the exhaust gases is given in Fig. 8.

Compared to the diesel fuel, measured $\mathrm{NO}_{2}$ emissions under $25 \%$ load conditions for B10 fuel decreased by $8.57 \%$. One explanation for this phenomenon is that the nitrogen dioxide $\left(\mathrm{NO}_{2}\right)$ can be converted to nitric oxide (NO) easily due to the high instability of carbon monoxide, especially under low engine load, which provides more reaction time due to slower burning rate during the combustion stroke. The reaction can be expressed by the equation:

$$
\mathrm{CO}(\mathrm{g})+\mathrm{NO}_{2}(\mathrm{~g})=\mathrm{CO}_{2}(\mathrm{~g})+\mathrm{NO}(\mathrm{g})
$$

The measured $\mathrm{NO}_{2}$ value decreased by $8.57 \%$ under $25 \%$ load conditions and changed slightly between a
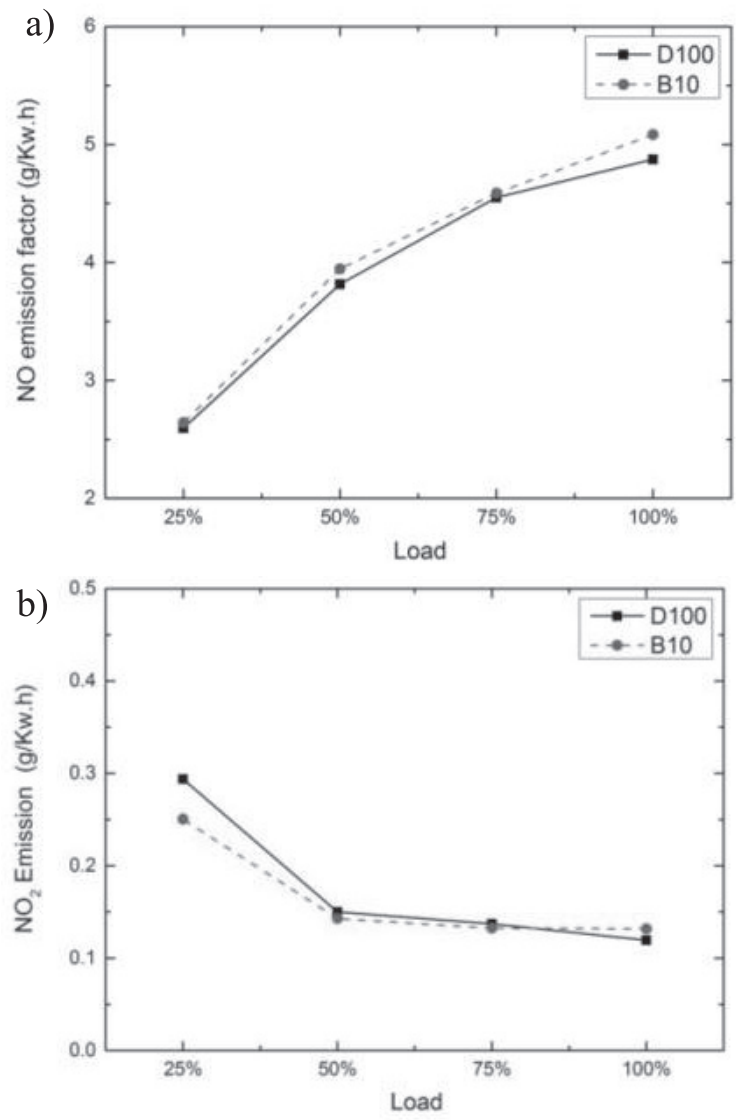

Fig. 7. a) NO emissions of biodiesel and diesel against load; b) $\mathrm{NO}_{2}$ emissions of biodiesel and diesel against load.

$50 \%$ to $75 \%$ load. However, it increased by $10.71 \%$ under $100 \%$ load as depicted in Fig. 7b). This observation can be attributed to increased fuel consumption as the load increased. Excessive fuel consumption under 100\% load condition for $\mathrm{B} 10$ resulted in high $\mathrm{NO}_{2}$ emissions. At the same time, the faster rate of combustion during the period under high engine load slowed the process of nitrogen dioxide being converted to nitric oxide, resulting in higher $\mathrm{NO}_{2}$ emissions under a high load for B10.

Fig. 8 shows the percentage of $\mathrm{NO}_{2}$ in $\mathrm{NO}_{\mathrm{x}}$ under different loads for $\mathrm{B} 10$ and $\mathrm{D} 100$. The $\mathrm{NO}_{2}$ rate decreases from about $10 \%$ to $2 \%$ with the increase in load for both fuels. The $\mathrm{NO}$ to $\mathrm{NO}_{2}$ conversion path within the engine system can be expressed as follows:

$$
\mathrm{NO}+\mathrm{HO}_{2} \rightarrow \mathrm{NO}_{2}+\mathrm{OH}
$$

The hydroperoxyl $\left(\mathrm{HO}_{2}\right)$ radicals are formed in relatively low-temperature regions. Hence, $\mathrm{NO}_{2}$ formation occurs when NO molecules from high temperature regions diffuse or are transported by fluid mixing into the $\mathrm{HO}_{2}$-rich regions. It is mainly temperature- rather than oxygen-related. Thus at higher engine load, the temperature is higher and hence the $\mathrm{NO}_{2}$ concentration is lower. Another critical factor affecting $\mathrm{NO}_{2}$ percentage is the oxygen content. After 
the combustion process, the oxygen concentration in exhaust gases decreases, resulting in a decrease in $\mathrm{NO}_{2}$ with the increasing load, as the ease of oxidizing NO to $\mathrm{NO}_{2}$ decreases.

Another possible reason for the decreased $\mathrm{NO}_{2}$ is the oxidation time. As the load increases, combustion temperature in the cylinder rise and the combustion rate increases as well. There is reduced time for the generated $\mathrm{NO}$ to be oxidized to $\mathrm{NO}_{2}$.

In comparison with the $\mathrm{NO}_{2}$ percentage, the $\mathrm{NO}_{2}$ percentage for B10 is slightly higher than that for D100. Compared to the diesel fuel, $\mathrm{NO}_{2}$ percentages under $25 \%, 50 \%, 75 \%$ and $100 \%$ load for B10 increased by $1.13 \%, 0.63 \%, 0.21 \%$ and $0.11 \%$, respectively. After the combustion process, the oxygen concentration in exhaust gases is slightly higher for B10 than D100, resulting in the higher $\mathrm{NO}_{2}$ percentage for B10 than diesel. The difference disappears as the load rises.

\section{PM and PN Emission}

Due to the slow sedimentation rate and long-term presence in the atmosphere, PM emissions are very harmful to human health. Fig. 9 shows that the use of biodiesel and its compound along with diesel results to a decrease in PM content in the engine exhaust gases. The same trend has been expressed by other researchers $[9$,
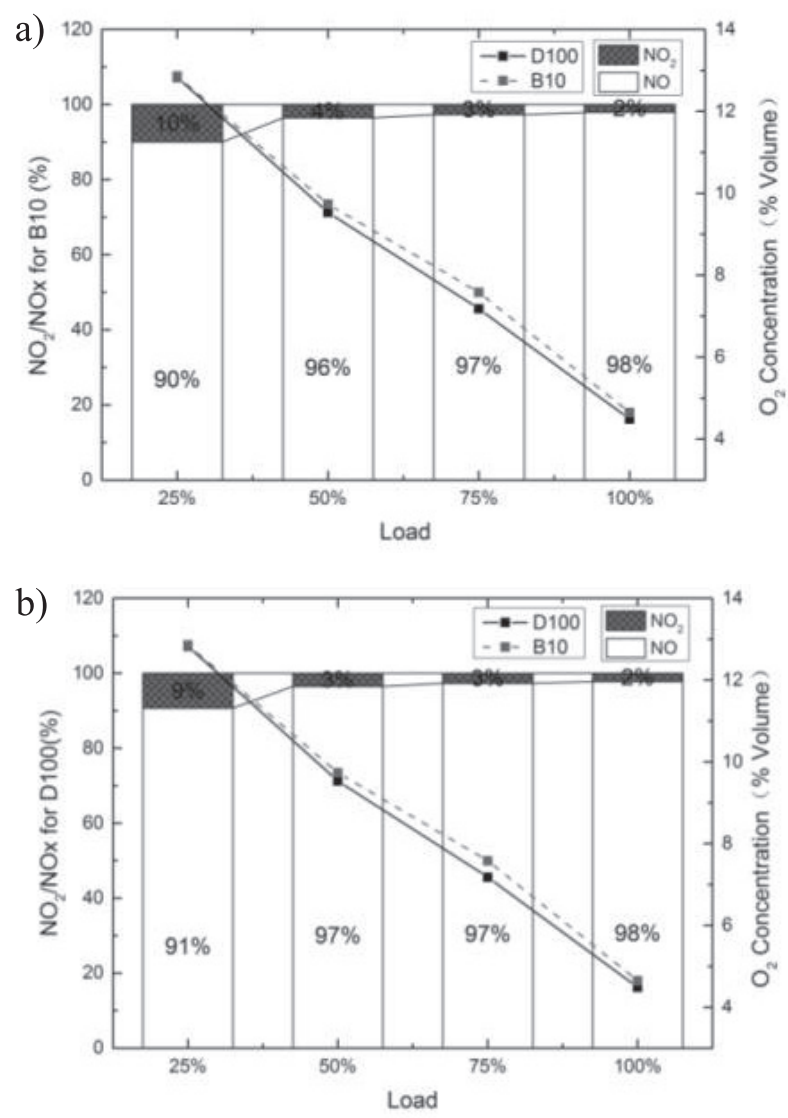

Fig. 8. a) $\mathrm{NO}_{2}$ conversion ratio of biodiesel against load; b) $\mathrm{NO}_{2}$ conversion ratio of diesel against load.
14, 28]. The existence of oxygen in biodiesel molecular structure results in better oxidation of PM during the combustion process. This, in turn, leads to a decrease in PM emissions for the engine run with biodiesel blend.

Fig. 9 shows the average PM emission, Fig. 9a) and PN emission, Fig. 9b) at different load conditions for B10 biodiesel and D100 diesel. About the diesel fuel, PM emission content under the four loads for B10 decreased by $54.11 \%, 12.48 \%, 11.92 \%$ and $5.60 \%$, respectively.

As can be seen, PM emissions for both fuels increased with the increasing speed due to the increased fuel consumption. The high oxygen content of the biodiesel fuel could have played a significant role in the combustion process. In areas with high concentrations of fuel, such as spray cores, the existence of oxygen in the fuel makes the combustion more complete. Also, one possible reason is the existence of fewer polycyclic aromatic hydrocarbons (PAHs) in B10 biodiesel and fewer $\mathrm{C}_{2} \mathrm{H}_{2}$ or $\mathrm{C}_{3} \mathrm{H}_{3}$ fragments in combustion products. It is the reduction of the precursors such as PAH that inhibits the formation of carbon smoke and the adsorption of SOF on carbon smoke.

Consistent with PM emissions, there are two inflection points in $\mathrm{PN}$ emissions with the increased load as in Fig. 9b). The reason for this phenomenon is that the high viscosity of the two fuels under low load results in poor atomization. For example, under $25 \%$
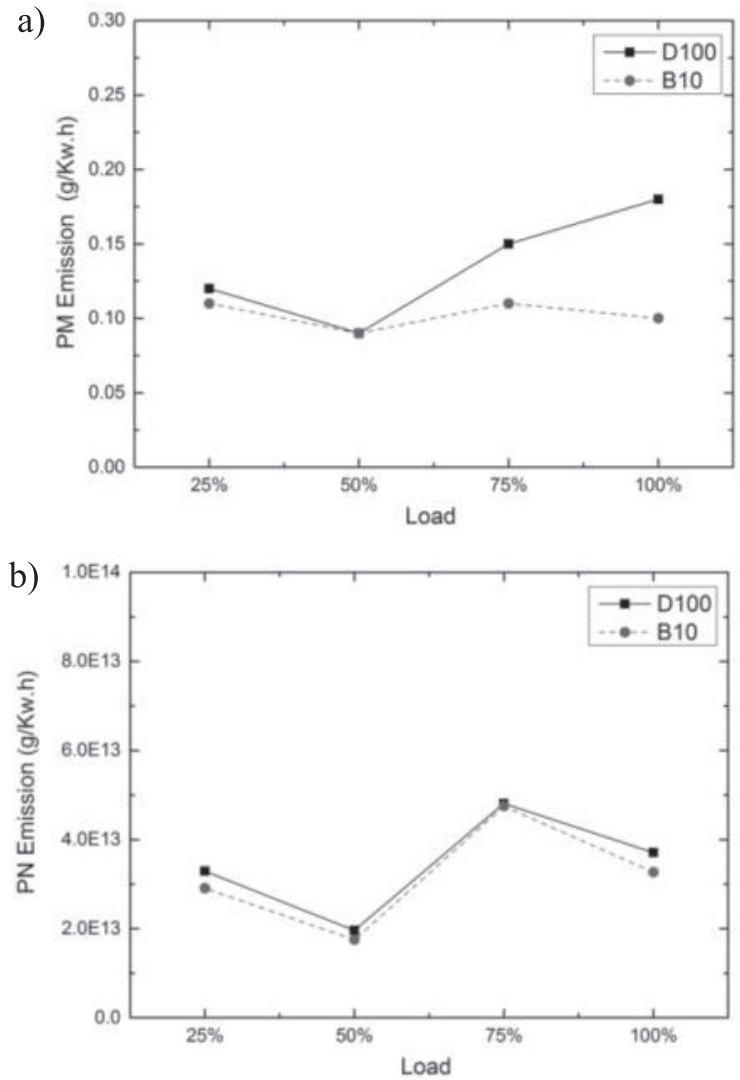

Fig. 9. a) PM emissions of biodiesel and diesel against load; b) PN emissions of biodiesel and diesel against load. 
it is easier to produce soluble organic fractions (SOF) and tiny carbon particles that constitute the nuclear state particles. As load increases, the effect of viscosity gradually diminishes, and combustion quality improves. PN emissions returned to low levels and increased with fuel consumption. Under high load, however, the high combustion temperature is conducive for the continuous oxidation of aggregated particles. The radius of particles is reduced to the range of nuclear size due to oxidation. Therefore, the PN at $100 \%$ load is less than that at $75 \%$.

In general, the PN is affected by many factors such as viscosity and temperature, but the oxidation process of aggregated particles may be a key factor. After burning biodiesel, with high oxygen content and high cetane number, the PN will decrease. For example, compared to diesel, PN emission under $25 \%, 50 \%, 75 \%$ and $100 \%$ loads for B10 decreased by $11.6 \%, 10.7 \%$, $1.25 \%$ and $11.9 \%$, respectively.

\section{Conclusions}

This study focused on the impact of waste cooking oil biodiesel blends (B10) on a marine propulsion diesel engine. Pollutant emissions were investigated experimentally. Based on the experiments, the main conclusions are summarized as follows.

The oxygen-containing properties of B10 biodiesel enhance the combustion process, which helps to reduce $\mathrm{CO}$, THC and PM emissions. More $\mathrm{CO}_{2}$ is released due to the increased fuel consumption and complete combustion. However, the oxygen content in B10 biodiesel does not contribute to heat generation, which results in a higher fuel consumption and relatively low BTE.

The rapid burning rate for $\mathrm{B} 10$ will reduce the radiation loss of the flame and increase the combustion temperature, which has a significant effect on $\mathrm{NO}_{\mathrm{x}}$ generation. The relatively high combustion temperature of B10 biodiesel promotes $\mathrm{NO}_{x}$ generation, which is mainly affected by $\mathrm{NO}$ amount.

By using B10 biodiesel, the $\mathrm{NO}_{2}$ emissions show a relatively complex trend under different engine loads. Oxidation is a significant factor for $\mathrm{NO}_{2}$ generation. The oxygen-containing properties of $\mathrm{B} 10$ biodiesel increase the oxygen concentration slightly after combustion, which increases the proportion of $\mathrm{NO}_{2}$ in $\mathrm{NO}_{x}$.

$\mathrm{PM}$ and PN are affected by many factors such as viscosity and temperature, but the oxidation process of aggregated particles may play an important role.

A future research focus will be on engine thermal performance, in-cylinder combustion process, response time characteristics under suddenly changing loads for a B10 biodiesel-fueled marine propulsion diesel engine. Vibration and wear performance of the marine propulsion diesel engine powered by biodiesel blends are also under our research plan.

\section{Acknowledgements}

The authors would like to acknowledge financial support from the NSFC projects of China under grant No. 61403250. The authors would like to acknowledge the financial support from the projects of Shanghai Science and Technology Commission under Grant No.18DZ1202902.

\section{Conflict of Interest}

The author declares no conflict of interest.

\section{References}

1. OMSTEDT A., EDMAN M., CLAREMAR B. Modeling the contributions to marine acidification from deposited SOx, NOx, and NHx in the Baltic Sea: past and present situation. Cont. Shelf Research, 111, 234, 2015.

2. PATEL C., AGARWAL A.K., TIWARI N., LEE S., LEE C.S., PARK S. Combustion, noise, vibrations and spray characterization for Karanja biodiesel fuelled engine. Applied Thermal Engineering, 106, 506, 2016.

3. SHEN G. Changes from traditional solid fuels to clean household energies - Opportunities in emission reduction of primary PM2.5 from residential cookstoves in China. Biomass and Bioenergy, 86, 28, 2016.

4. KOWALSKI J. An experimental study of emission and combustion characteristics of marine diesel engine with fuel pump malfunctions. Applied Thermal Engineering, 65 (1-2), 469, 2014.

5. ANGEETA MOKA S., PANDE M., RANI M., GAKHAR R., SHARMA M., RANI J.B. A. Alternative fuels: an overview of current trends and scope for future. Renew Sustain Energy Rev., 32, 697, 2014.

6. MAHMUDUL H.M., HAGOS F.Y., MAMAT R., ADAM A.A., ISHAK W.F.W., ALENEZI R. Production, characterization and performance of biodiesel as an alternative fuel in diesel engines - A review. Renewable and Sustainable Energy Reviews, 72 (April 2016), 497, 2017.

7. TESFA B., MISHRA R., ZHANG C., GU F., BALL A.D. Combustion and performance characteristics of $\mathrm{CI}$ (compression ignition) engine running with biodiesel. Energy, 51, 101, 2013.

8. AGARWAL A.K. Biofuels (alcohols and biodiesel) applications as fuels for internal combustion engines. Progress in Energy and Combustion Science. 2007.

9. DATTA A., MANDAL B.K. A comprehensive review of biodiesel as an alternative fuel for compression ignition engine. Renewable and Sustainable Energy Reviews, 57, $799,2016$.

10. DEEPANRAJ B., P. LAWRENCE R., SIVASHANKAR V.S. Analysis of preheated crude palm oil, palm oil methyl ester and its blends as fuel in a diesel engine. International Journal of Ambient Energy. 2015.

11. MOHAMMADI P., NIKBAKHT A.M., TABATABAEI M., FARHADI K., MOHEBBI A., KHATAMI FAR M. Experimental investigation of performance and emission characteristics of DI diesel engine fueled with polymer waste dissolved in biodiesel-blended diesel fuel. Energy, 46 (1), 596, 2012. 
12. MUSA I. A. The effects of alcohol to oil molar ratios and the type of alcohol on biodiesel production using transesterification process. Egyptian Journal of Petroleum, 25 (1), 21, 2016.

13. ATTIA A.M.A., HASSANEEN A.E. Influence of diesel fuel blended with biodiesel produced from waste cooking oil on diesel engine performance. Fuel, 167, 316, 2016.

14. LIN Y.C., HSU K.H., CHEN C.B. Experimental investigation of the performance and emissions of a heavy-duty diesel engine fueled with waste cooking oil biodiesel/ultra-low sulfur diesel blends. Energy, 36 (1), 241, 2011.

15. ZAREH P., ZARE A.A., GHOBADIAN B. Comparative assessment of performance and emission characteristics of castor, coconut and waste cooking based biodiesel as fuel in a diesel engine. Energy, 139, 883, 2017.

16. KNOTHE G., RAZON L.F. Biodiesel fuels. Progress in Energy and Combustion Science, 58, 36, 2017.

17. SAKA S., KUSDIANA D. Biodiesel fuel from rapeseed oil as prepared in supercritical methanol. Fuel, 80 (2), 225, 2001.

18. ROY M.M., WANG W., BUJOLD J. Biodiesel production and comparison of emissions of a DI diesel engine fueled by biodiesel-diesel and canola oil-diesel blends at high idling operations. Applied Energy, 106, 198, 2013.

19. CHAUHAN B.S., KUMAR N., CHO H.M., LIM H.C. A study on the performance and emission of a diesel engine fueled with Karanja biodiesel and its blends. Energy, 56, $1,2013$.

20. ÖNER C., ALTUN Ş. Biodiesel production from inedible animal tallow and an experimental investigation of its use as alternative fuel in a direct injection diesel engine. Applied Energy, 86 (10), 2114, 2009.

21. WANG R., HANNA M.A., ZHOU W.W., BHADURY P.S., CHEN Q., SONG B.A., YANG S. Production and selected fuel properties of biodiesel from promising non-edible oils: Euphorbia lathyris L., Sapium sebiferum L. and Jatropha curcas L. Bioresource Technology, 102 (2), 1194, 2011.

22. LU H., LIU Y., ZHOU H., YANG Y., CHEN M., LIANG B. Production of biodiesel from Jatropha curcas L. oil. Computers and Chemical Engineering, 33 (5), 1091, 2009.

23. HUZAYYIN A.S., BAWADY A.H., RADY M.A., DAWOOD A. Experimental evaluation of Diesel engine performance and emission using blends of jojoba oil and Diesel fuel. Energy Conversion and Management, 45 (1314), 2093, 2004.

24. PUGAZHVADIVU M., JEYACHANDRAN K. Investigations on the performance and exhaust emissions of a diesel engine using preheated waste frying oil as fuel. Renewable Energy, 30 (14), 2189, 2005.
25. UYUMAZ A. Combustion, performance and emission characteristics of a DI diesel engine fueled with mustard oil biodiesel fuel blends at different engine loads. Fuel, 212 (August 2016), 256, 2018.

26. EL-ADAWY M., IBRAHIM A.E.-K.M. An Experimental Evaluation of using Waste Cooking Oil Biodiesel in a Diesel. Energy Technology, 1 (12), 726, 2013.

27. RAMOS M.J., FERNÁNDEZ C.M., CASAS A., RODRÍGUEZ L., PÉREZ Á. Influence of fatty acid composition of raw materials on biodiesel properties. Bioresource Technology, 100 (1), 261, 2009.

28. ASHRAFUL A.M., MASJUKI H.H., KALAM M.A., RIZWANUL FATTAH I.M., IMTENAN S., SHAHIR S.A., MOBARAK H.M. Production and comparison of fuel properties, engine performance, and emission characteristics of biodiesel from various non-edible vegetable oils: A review. Energy Conversion and Management, 80, 202, 2014.

29. MARTÍNEZ G., SÁNCHEZ N., ENCINAR J.M., GONZÁLEZ J.F. Fuel properties of biodiesel from vegetable oils and oil mixtures. Influence of methyl esters distribution. Biomass and Bioenergy, 63, 22, 2014.

30. THALLES A.A., MASSIMILIANO E.K.V. Influence of the reaction conditions on the enzyme-catalyzed transesterification of castor oil: a possible step in biodiesel production. Bioresour Technol., 243, 366, 2017.

31. BEHÇET, R. Performance and emission study of waste anchovy fish biodiesel in a diesel engine. Fuel Processing Technology, 92 (6), 1187, 2011.

32. RAHEMAN H., PHADATARE A.G. Diesel engine emissions and performance from blends of karanja methyl ester and diesel. Biomass and Bioenergy, 27 (4), 393, 2004.

33. MOFIJUR M., RASUL M.G., HYDE J. Recent developments on internal combustion engine performance and emissions fuelled with biodiesel-diesel-ethanol blends. Procedia Engineering, 105 (Icte 2014), 658, 2015.

34. MOHSIN R., MAJID Z.A., SHIHNAN A.H., NASRI N.S., SHARER Z. Effect of biodiesel blends on engine performance and exhaust emission for diesel dual fuel engine. Energy Conversion and Management, 88 (x), 821, 2014.

35. CHONG C.T., NG J.H., AHMAD S., RAJOO S. Oxygenated palm biodiesel: Ignition, combustion and emissions quantification in a light-duty diesel engine. Energy Conversion and Management, 101, 317, 2015.

36. ARBAB M.I., VARMAN M., MASJUKI H.H., KALAM M.A., IMTENAN S., SAJJAD H., RIZWANUL FATTAH I.M. Evaluation of combustion, performance, and emissions of optimum palm-coconut blend in turbocharged and non-turbocharged conditions of a diesel engine. Energy Conversion and Management, 90, 111, 2015. 
